\title{
Prevalence and Predisposing Factors of Human Immunodeficiency Virus Infection among the Boda-Boda Riders in Mbarara Municipality-Uganda
}

\author{
Mathias Tumwebaze ${ }^{*}\left(\mathbb{D}\right.$, Emmanuel O. Otiam² $^{2}$, Kakwezi Margaret Rukindo ${ }^{3}$, John Mwesigwa ${ }^{4}$ \\ ${ }^{1}$ Department of Public Health, Bishop Stuart University, Mbarara, Uganda \\ ${ }^{2}$ Kitagata Hospitals, Ministry of Health, Kitagata, Uganda \\ ${ }^{3}$ District Health Team, Kabarole District Local Government, Fort Portal, Uganda \\ ${ }^{4}$ Uganda Martyrs University, Nkozi, Uganda \\ Email: *mathiastumwebaze@gmail.com, otiam04@gmail.com, rukindomargaret@gmail.com, mwesigwaj@gmail.com
}

How to cite this paper: Tumwebaze, M., Otiam, E.O., Rukindo, K.M. and Mwesigwa, J. (2020) Prevalence and Predisposing Factors of Human Immunodeficiency Virus Infection among the Boda-Boda Riders in Mbarara Municipality-Uganda. Open Journal of Epidemiology, 10, 235-250. https://doi.org/10.4236/ojepi.2020.103021

Received: May 30, 2020

Accepted: July 6, 2020

Published: July 9, 2020

Copyright $\odot 2020$ by author(s) and Scientific Research Publishing Inc. This work is licensed under the Creative Commons Attribution International License (CC BY 4.0).

http://creativecommons.org/licenses/by/4.0/

(c) (i) Open Access

\begin{abstract}
Background: Boda-Boda is a well-known and booming motorcycle taxi that employs youths to earn a living. They transport passengers at a faster rate where other means of transport are inaccessible or would be time consuming. Global statistics show that HIV has continued to be a major global Public Health issue especially among the "Most At-risk Populations" (MAPs) that include commercial transporters and Boda-Boda riders. Aim: This study aimed at assessing the prevalence and predisposing factors for HIV/AIDS among Boda-Boda riders living in Mbarara Municipality. Specifically, the study determined the prevalence of HIV among the Boda-Boda riders, identified social demographic predisposing factors for HIV and determined knowledge of Boda riders on prevention of HIV. Study setting: Boda-Boda operators in the transport sector are at high risk of HIV infection but the HIV status of the Boda Riders in Mbarara was not known a reason why the study was instituted: Study design: This was an analytical and descriptive cross-sectional study that employed quantitative methods of data collection. The study population comprised the registered Boda-Boda operators from two divisions of Kakoba and Kakiika in Mbarara municipality. Sample size and sampling methods: Using Morgan's table (1970), the population of the registered Boda Riders was 15,041; this corresponded to a sample size of 375 respondents by Morgan Table. Systematic sampling procedure was used to get every 3rd registered rider on the list. Data collection: A pre-tested structured tool aided data collection after group pretest counseling. Individual counseling was also done prior to testing and giving results. The laboratory technologists drew
\end{abstract}


blood to determine the sero-status of the respondents. Results were recorded as tested reactive (TRR) or tested non-reactive (TR). Unigold was used as tie breaker to confirm their diagnosis in order to ascertain those who were HIV positive on determine. Data analysis: Analysis was done at univariate, bivariate and multivariate using STATA version 13, Statistical significance of the relationship was determined for the $\mathrm{p}$-value $(\mathrm{p} \leq 0.05)$. Significant variables were then considered at multivariate level of analysis. Results: More than half 195 (52\%) of the Boda-Boda cyclist had attained primary level of education and $36.5 \%$ secondary education. HIV prevalence among Boda-Boda riders was $9.9 \%$. Riders who had never heard of VCT/HCT screening for HIV were three times likely to acquire HIV compared to those who ever heard of VCT/HCT screening (OR = 3.35; 95\% CI 1.14 9.83; $\mathrm{p}=0.027$ ). Those with multiple partners were six times more likely to acquire HIV/AIDS compared to those who buy sex from prostitutes $(\mathrm{OR}=6.13$; 95\% CI $1.5424 .38 ; \mathrm{p}=$ $0.01)$. The level of awareness of VCT was found high at (94.7\%), and the general knowledge about utilization and importance of VCT services was at $80 \%$, however condom use as a preventive measure was found low at $44.3 \%$ among the respondent Boda-Boda riders. Conclusion: Boda-Boda riders had high HIV prevalence of $9.9 \%$ compared to that of Mbarara district at $6.1 \%$ and much higher than $5.7 \%$ national HIV prevalence level. The predisposing factors to acquire HIV/AIDS were having multiple sexual partners, not having heard of HIV counseling and testing as well as low and inconsistent condom use at $44.3 \%$. The study recommends health service providers and HIV counselors to intensify awareness and behavior change campaigns on condom use among the Boda-Boda riders as preventive measure against HIV.

\section{Keywords}

Boda-Boda Riders, HIV Prevalence in Boda-Boda, VCT/HCT Screening for HIV, Condom Use

\section{Introduction}

Boda-Boda is a coined term in East Africa which originally referred exclusively to bicycle taxis and has in recent years, been expanded to refer to motorcycle taxis as well as tricycles [1]. It is one of the booming transport sectors in Uganda that employs a large number of youths to earn a living. In Uganda riding Boda Bodas has become a considerable source of income in almost all the districts for many youths, providing livelihood to themselves and their families [2]. In Uganda, Boda-Boda industry employs an estimated 250,000 youth (Kampala alone) and a source of livelihood to over 500,000 people in the country [3]. Daily monitor newspaper Uganda 2013, reported that Uganda spends 80 billion Ugandan shillings annually buying Indian bikes [4] and the country ranked third in motorcycle imports from India, behind Nigeria and Angola [4]. UN report (2018) shows that the Boda Bodas are so widespread in Uganda, and this sector is claimed to be the second largest employer of Ugandans [5]. 
Despite the significant contribution of the transport sector to Uganda's national development, there is unprecedented problem of HIV/AIDS seen elsewhere as an occupational hazard among truck drivers and motorcycle riders due to their lifestyle while on duty [6]. Studies done in Uganda and elsewhere have revealed transport as a social sector in the transmission of HIV in addition to other high risk behaviors like commercial sex work that fuel HIV epidemic. Transport sector workers serve as bridge populations linking with the general population increasing their HIV infection acquisition risk twofold as workers in low-risk occupations and young people in the population [7].

Global statistics by UNAIDS 2019, show that HIV has continued to be a major global Public Health issue. By end of 2018, 44 million people globally were living with HIV; a cumulative total of up to 78.1 million had been infected since the start of epidemic and approximately 8.1 million did not know their HIV status [8].

Studies have shown that HIV/AIDS disproportionately affects population and the risk has been found very high among special groups of people categorised as most at Risk [9]. These include drug users, transgender, sex workers, and men who have sex with men. Other than what is mentioned here, ranking high in behaviour risk are long distance truck drivers and the Boda-Boda riders who are mainly youths that are sexually active, adventurous and vulnerable to acquire HIV/AIDS. The transport sector in general is a means of spread and transmission of HIV/AIDS because of the constant stream of large numbers of people along transport routes. The term Boda-Boda originated from eastern Uganda, in towns bordering Kenya and Uganda like Busia, Malaba and Lwakaka: It referred to boys/men on bicycles who offered to smuggle goods and individuals across the border. The term "Boda-Boda" itself is the way Ugandans and Kenyans pronounce the phrase "border-border" when offering their services [10]. While Boda-Boda initially existed solely in the form of bicycle transportation, the term soon grew to encompass those who offered motorcycle transportation as well. The risk of HIV infection among the Boda-Boda elsewhere is influenced among others by, low knowledge levels on HIV transmission and prevention, limited access to HIV counseling and Testing (HCT) to establish one's sero-status and low condom use. HCT has proved very successful as a form of HIV prevention in Eastern and Southern Africa [11]. A study in South Africa found that HIV testing and Counseling among 4000 young people meant $41 \%$ fewer cases of HIV transmission in a four year period [12].

Studies have demonstrated that Condom use is an important strategy that helps prevent HIV transmission by reducing the risk of an exposure to HIV during sex [13]. This is because a condom provides a physical barrier to the virus. However Condom use among young people and adolescents Boda-Boda riders not exceptional remains relatively low. Demographic and Health Surveys conducted in sub-Saharan Africa between 2010 and 2015 report less than $60 \%$ of young women (aged 15 to 24) with multiple partners used a condom during their last sexual intercourse in 19 of 23 countries. In 15 out of 23 countries, there 
were similar results for young men [14]. Studies elsewhere have also shown that the risk of low condom use among the young people is further compounded by having multiple sexual partners. This is seen in countries mostly affected by HIV pandemic [15]. A case in point is that of Lesotho, Madagascar and Eswatini where more than a quarter of young men have been found to have multiple relationships [16].

Boda-Boda riders having been identified as being highly vulnerable to HIV transmission through the transport sector because of their engagement in risky behavior, the need for critical investigation of this problem is ostensible. There is no study that has been carried out to ascertain the prevalence of HIV infection among the Boda-Boda in Mbarara Municipality, therefore information on prevalence and social demographic risks in this population is virtually non-existent. Results of this study should be of value to Mbarara municipality health services for planning specific intervention for Boda-Boda as a high-risk group.

\section{Methodology}

Study design: This was an analytical cross-sectional study that employed quantitative methods of data collection. The study population comprised of the registered Boda-Boda operators from two divisions of Kakoba and Kakiika in Mbarara municipality where the study was conducted. Sample size and sampling methods: using Morgan's table (1970), the population of the registered Boda Riders was 15,041; this corresponded to a sample size of 375 respondents by Morgan Table. Systematic sampling procedure was used to get every 3rd registered rider on the list. Data collection: a pre-tested structured tool aided data collection after group pretest counseling. Individual counseling was done prior to testing and giving results. The laboratory technologists drew blood to determine the sero-status of the respondents. Results were recorded as tested reactive (TRR) or tested non-reactive (TR). Unigold was used as tie breaker to confirm their diagnosis in order to ascertain those who were HIV positive on determine.

Ethical consideration: The study protocol was reviewed and approved by Bishop Stuart University Ethics and Research Committee and written permission obtained from the Town clerk of Mbarara Municipality. Informed written consent in Runyankore or English a language understandable to the respondents was signed by every respondent before participation in the study. All the respondents were above 16 years of age therefore, signed the consent forms themselves. Interviews were done in centrally located health facilities. These were Nyamityobora Health center II, St Hellen clinic Kakoba round, Mayanja training Institute and Makenke UPDF hospital on different schedules.

Data analysis: Analysis was done at univariate, bivariate and multivariate using STATA version 13, Statistical significance of the relationship was determined for the $\mathrm{p}$-value $(\mathrm{p} \leq 0.05)$. Significant variables were then considered at multivariate level of analysis. The multivariate analysis was performed to assess which factor predisposes the Boda-Boda riders to HIV more than the other. The de- 
pendent variable, Current HIV result is either "positive" or "negative" which was a categorical variable with two level/categories and therefore the suitable model to analyze this kind of dependent variable is the logistic regression model. Logistic regression analysis was used because it attempts to control for possible confounding effects of independent variables on each other and thus found the independent association for each independent variable with the dependent variable.

\section{Results}

1) Characteristics of study participants: A total of 375 male Boda-Boda riders median age 26.1 years were enrolled in the study pre-counseled and tested for HIV in October-November 2019. Slightly more than a half of the riders 216 (57.6\%) were married with number of wives ranging from 1 to more than three, the rest 114 (30.4\%) and 38 (10.13\%) were single and cohabiting respectively, three quarters 293 (78\%) resided in Kakoba division, 81 (22\%) in Kakika division (Table 1).

Slightly more than a half 195 (52\%) had completed primary level of education, 137 (36.5\%) secondary level. Less than a half 172 (47\%) were Protestants while 117 (31.62\%) were Catholics the rest being Muslims and Pentecostals. Table 1 further reveals that, 20 (15.4\%) riders of the married riders had two other sexual partners, 6 (4.6\%) had 3 and $11(8.5 \%)$ with more than 3. Almost a half of the Boda-Boda riders 174 (46.4\%) had been riders for more than 3 years.

\section{2) Prevalence of HIV among Boda-Boda riders}

Using determine strips first, those tested reactive were confirmed using Unigold. Overall HIV prevalence among the Boda-Boda riders was 9.9\% (Table 2 below). About 292 riders were tested from Kakoba division and 81 from Kakika division. The prevalence of HIV was highest (13.6\%) in Kakika division and slightly lower $8.9 \%$ in Kakoba division. Prevalence among the single riders and those with one wife was $9.3 \%$, those with more than three girlfriends/lovers $18.2 \%$ ), those of Rwandese origin $18.2 \%$. Among those that completed primary level of education (12\%), those who had never heard of HIV/AIDS screening $25 \%$, among the riders who said that HIV cannot be cured (10\%) while those having more than one partner (multiple partners) it was $38 \%$.

\section{3) Boda-Boda riders' knowledge on HIV and HCT screening}

From Table 3: Most riders, 355 (95\%) had ever heard about VCT/HIV/ AIDS screening with 355,198 (57\%) getting information about HIV and HCT from the health workers. More than three quarters $292(80 \%)$ of the riders knew the definition of the VCT/HCT while 231 (64\%) knew that everyone benefits from VCT.

\section{4) Attitude towards VCT screening for HIV}

Study findings in Table 4 revealed that less than a half 172 (47\%) of the riders are always ready for HIV results no matter the outcome while majority 303 (82\%) knew that HIV/AIDS cannot be cured. Nearly all 316 (92\%) of the riders 
Table 1. Description of participants.

\begin{tabular}{|c|c|}
\hline \multicolumn{2}{|l|}{ Socio-demographic factors } \\
\hline Marital status $(n=375)$ & n (\%) \\
\hline Single & $114(30.4)$ \\
\hline Cohabiting & $38(10.13)$ \\
\hline Married & $216(57.6)$ \\
\hline Separated & $6(1.6)$ \\
\hline Widower & $1(0.27)$ \\
\hline \multicolumn{2}{|l|}{ Number of wives $(n=220)$} \\
\hline One & $204(91.9)$ \\
\hline Two & $15(6.8)$ \\
\hline Three & $2(0.9)$ \\
\hline More than Three & $1(0.5)$ \\
\hline \multicolumn{2}{|l|}{ Religion $(\mathrm{n}=370)$} \\
\hline Protestant & $172(46.5)$ \\
\hline Catholic & $117(31.6)$ \\
\hline Moslem & $58(15.7)$ \\
\hline Pentecost & $23(6.2)$ \\
\hline \multicolumn{2}{|l|}{ No. of girlfriends $(n=130)$} \\
\hline One & $93(71.5)$ \\
\hline Two & $20(15.4)$ \\
\hline Three & $6(4.6)$ \\
\hline More than three & $11(8.5)$ \\
\hline \multicolumn{2}{|l|}{ Residence-Division (375) } \\
\hline Kakoba & $293(78.3)$ \\
\hline Kakika & $82(21.7)$ \\
\hline \multicolumn{2}{|l|}{ Socio-economic factors } \\
\hline \multicolumn{2}{|l|}{ Education level of Boda-Boda riders (375) } \\
\hline None & $12(3.2)$ \\
\hline Primary & $195(52)$ \\
\hline Secondary & $137(36.5)$ \\
\hline Tertiary & $31(8.3)$ \\
\hline \multicolumn{2}{|l|}{ Duration spent as Boda-Boda riders $(n=375)$} \\
\hline Less than a year & $35(9.3)$ \\
\hline One year & $39(10.4)$ \\
\hline Two years & $68(18.1)$ \\
\hline Three years & $59(15.7)$ \\
\hline More than three years & $174(46.4)$ \\
\hline Summary statistics of the age of Boda-Boda riders $(n=357)$ & Age Range ( $\min -\max )$ \\
\hline Median age and age range & $26.1(17-42)$ \\
\hline
\end{tabular}


Table 2. HIV Prevalence (percent distribution) among Boda-Boda riders.

\begin{tabular}{|c|c|c|c|c|c|}
\hline \multirow[b]{3}{*}{ Marital status } & \multicolumn{4}{|c|}{ Current HIV result } & \multirow{3}{*}{ Total } \\
\hline & \multicolumn{2}{|c|}{ Negative } & \multicolumn{2}{|c|}{ Positive } & \\
\hline & $\mathrm{n}$ & $\%$ & $\mathrm{n}$ & $\%$ & \\
\hline Single & 101 & 88.6 & 13 & 11.4 & 114 \\
\hline Cohabiting & 33 & 89.2 & 4 & 10.8 & 37 \\
\hline Married & 197 & 91.2 & 19 & 8.8 & 216 \\
\hline Separated & 5 & 83.3 & 1 & 2.7 & 6 \\
\hline Widower & 1 & 100.0 & 0 & 0.0 & 1 \\
\hline \multicolumn{6}{|l|}{ Number of wives } \\
\hline One & 185 & 90.7 & 19 & 9.3 & 204 \\
\hline Two & 15 & 100.0 & 0 & 0.0 & 15 \\
\hline Three & 2 & 100.0 & 0 & 0.0 & 2 \\
\hline More than three & 1 & 100.0 & 0 & 0.0 & 1 \\
\hline \multicolumn{6}{|c|}{ Number of girls friends/lovers } \\
\hline One & 81 & 87.1 & 12 & 12.9 & 93 \\
\hline Two & 19 & 95.0 & 1 & 5 & 20 \\
\hline Three & 5 & 100.0 & 0 & 0.0 & 5 \\
\hline More than three & 9 & 81.8 & 2 & 18.2 & 11 \\
\hline \multirow{2}{*}{ Parameter } & \multicolumn{4}{|c|}{ Current HIV result } & \\
\hline & \multicolumn{2}{|c|}{ Negative (-) } & \multicolumn{2}{|c|}{ Positive (+) } & Total \\
\hline Residence/Division & $\mathrm{n}$ & $\%$ & $\mathrm{n}$ & $\%$ & \\
\hline Kakoba & 266 & 91.1 & 26 & 8.9 & 292 \\
\hline Kakika & 70 & 86.4 & 11 & 13.6 & 81 \\
\hline \multicolumn{6}{|l|}{ Tribe } \\
\hline Banyankole & 233 & 88.9 & 29 & 11.1 & 262 \\
\hline Bakiga & 60 & 92.3 & 5 & 7.7 & 65 \\
\hline Baganda & 29 & 96.7 & 1 & 3.3 & 30 \\
\hline Rwandese & 9 & 81.8 & 2 & 18.2 & 11 \\
\hline \multicolumn{6}{|l|}{ Education level } \\
\hline None & 11 & 91.67 & 1 & 8.33 & 12 \\
\hline Primary & 172 & 88.21 & 23 & 11.79 & 195 \\
\hline Secondary & 123 & 90.44 & 13 & 9.56 & 136 \\
\hline Tertiary & 31 & 100.0 & 0 & 0.0 & 31 \\
\hline \multirow{2}{*}{ Parameter } & \multicolumn{4}{|c|}{ Current HIV result } & \\
\hline & \multicolumn{2}{|c|}{ Negative } & \multicolumn{2}{|c|}{ Positive } & Total \\
\hline \multicolumn{6}{|l|}{ Can HIV be cured? } \\
\hline Yes & 60 & 90.91 & 6 & 9.09 & 66 \\
\hline No & 271 & 89.74 & 31 & 10.26 & 302 \\
\hline
\end{tabular}




\section{Continued}

Consideration before using condoms

$\begin{array}{lccccc}\text { Date of manufacture } & 196 & 90.7 & 20 & 9.3 & 216 \\ \text { No damage seen } & 1 & 100.0 & 0 & 0.0 & 1 \\ \text { still in its cover } & 1 & 50.0 & 1 & 50.0 & 2 \\ \text { Open from ZigZag edge } & 1 & 50.0 & 1 & 50.0 & 2 \\ \begin{array}{l}\text { Have you ever heard of } \\ \text { /HCT screening for HIV? }\end{array} & & & & & \\ \quad \text { Yes } & 322 & 90.96 & 32 & 9.04 & 354 \\ \quad \text { No } & 15 & 75.00 & 5 & 25.00 & 20\end{array}$

What was the source of information?

$\begin{array}{cccccc}\text { Friends } & 73 & 89.02 & 9 & 10.98 & 82 \\ \text { radio/TV } & 62 & 95.38 & 3 & 4.62 & 65 \\ \text { Health worker } & 177 & 89.85 & 20 & 10.15 & 197 \\ \text { Others } & 2 & 100.0 & 0 & 0.00 & 2\end{array}$

Table 3. Boda-Boda rider's knowledge on HIV and HCT screening.

\begin{tabular}{cc}
\hline \multicolumn{2}{c}{ Variables } \\
\hline Ever heard VCT/HIV/AIDS screening & n (\%) \\
\hline No & $355(94.7)$ \\
Definition of VCT/HCT screening for HIV & $20(5.3)$ \\
A screen for people to get result of HIV & $23(6.3)$ \\
Voluntary counseling and testing for HIV & $292(80.4)$ \\
It is a disease that can be screened in blood & $23(6.3)$ \\
I don't know & $25(6.9)$ \\
Respondents knowledge on a Group of people who benefit from VCT & $63(17.3)$ \\
People with weak immunity & $6(1.7)$ \\
People who are always bed ridden & $7(1.9)$ \\
Children of a man who died of HIV & $231(63.5)$ \\
Everyone & $57(15.7)$ \\
\hline
\end{tabular}

Table 4. Attitude towards VCT screening for HIV.

\begin{tabular}{lc}
\hline \multicolumn{2}{c}{ Variables } \\
\hline What are your feelings towards drawing blood from you for a HIV test. $(\mathbf{n}=355)$ & $\mathbf{n}(\%)$ \\
\hline - Like knowing my status & $141(39.7)$ \\
- Painless procedure & $3(0.85)$ \\
- I fear the results & $26(7.3)$ \\
- Because its voluntary, people are always ready for the results no matter the & $172(48.5)$ \\
& outcome \\
- I don't know & $13(3.7)$ \\
\hline
\end{tabular}




\section{Continued}

\section{Can HIV be cured?}

- Yes

- No

How are HIV patients managed?

- By praying

- By taking all the medicines given correctly throughout lifetime

- By taking all the medicines as prescribed until one feels better

- I don't know

\section{Do you feel people with HIV should get treatment} and continue riding bodaboda?

- Yes

- No

\section{Where should they get treatment?}

- Pastors who will pray for them

- Traditional healers who will consult to forgive them

- To the drug shops or pharmacies and buy drugs for themselves

- Should go to the hospital/health facility for free HIV treatment

Do you believe that HIV/AIDS kills?

- Yes

- No

\section{If yes, who does it kill?}

- Those who don't comply with medical treatment

- Those who don't repent to God

- Those who refuse to appease the ancestors

- All those who are not infected

- I don't know

Do you agree that people with HIV should stay together with their family members?

- Yes

- No

If yes, why should they stay together? (give reasons)

- Because they cannot infect them

- Because they need love and support from their family members

- Because they can die without them

were aware that HIV patients are managed by taking all the medicine given correctly throughout lifetime and majority 336 (90\%) felt that Boda-Boda riders with HIV should get treatment and continue riding Boda-Boda. Three quarters 
$273(75 \%)$ suggested that riders with HIV should go to the Health facility for free HIV treatment.

5) Practices towards Voluntary Counselling and Testing (VCT) screening for HIV

Nearly all the riders 360 (96\%) had ever tested for HIV or attended VCT services, 360 (97\%) mentioned that they would go to the hospital in case they test positive for HIV so that they get treatment, a low percent of $44 \%$ of the Boda-Boda riders had used condoms before as a preventive measure to avoid HIV/AIDS (Table 5).

Table 5. Practices on VCT screening for HIV.

\begin{tabular}{lc}
\hline \multicolumn{2}{c}{ Variables } \\
\hline Have you ever had voluntary counseling and testing for HIV or VCT? & n (\%) \\
\hline Yes & $360(96.0)$ \\
No & $15(4.0)$ \\
What will you do if your present test is positive for AIDS? & $8(2.1)$ \\
I will consult a herbalist/traditional healer for treatment & $360(96.5)$ \\
I will go to the hospital/health facility to get my blood examined again and treated & $2(0.54)$ \\
I will go to the pastors for prayers & $3(0.80)$
\end{tabular}

What should you do when someone in your community tells you that they have HIV?

Stay away from that perso

Encourage him/her to take her medications as prescribed by the doctor

Stay with him to know more about signs and symptoms of HIV

What current preventive measures are you using to avoid HIV in your community today?

Avoid HIV patients

Use of masks, overalls and gloves in a community with HIV patients

Mention the risks that can make an adult acquire HIV/AIDS

Not using a condom regularly 
6) Association between social demographic exposure variables and current HIV status of the riders. In Table 6 below, HIV exposure risk factors were examined using Pearson Chi-Square and Fisher's exact. Results were regarded as statistically significant with P-value less than 0.05 . Findings show that, there was a statistically significant relationship between ever heard about VCT/HCT screening for HIV by Boda-Boda riders and current HIV result. Pearson Chi-Square

Table 6. Associations between HIV status and Boda-Boda cyclists' characteristics.

\begin{tabular}{|c|c|c|c|c|}
\hline \multirow{2}{*}{ Parameter } & \multicolumn{3}{|c|}{ Pearson chi square tests } & \multirow{2}{*}{$\begin{array}{c}\text { Fisher's exact } \\
\text { p-value }\end{array}$} \\
\hline & Total & $x^{2}$ & p-value & \\
\hline \multicolumn{5}{|l|}{ Marital status } \\
\hline Single & 114 & \multirow{5}{*}{1.0368} & \multirow{5}{*}{0.904} & \\
\hline Cohabiting & 37 & & & \\
\hline Married & 216 & & & \\
\hline Separated & 6 & & & \\
\hline Widower & 1 & & & \\
\hline \multicolumn{5}{|l|}{ No. wives } \\
\hline One & 204 & \multirow{4}{*}{1.8334} & \multirow{4}{*}{0.608} & \multirow{4}{*}{0.521} \\
\hline Two & 15 & & & \\
\hline Three & 2 & & & \\
\hline More than three & 1 & & & \\
\hline \multicolumn{5}{|c|}{ No. of girls friends/lovers } \\
\hline One & 93 & \multirow{4}{*}{2.1199} & \multirow{4}{*}{0.548} & \multirow{4}{*}{0.635} \\
\hline Two & 20 & & & \\
\hline Three & 5 & & & \\
\hline More than three & 11 & & & \\
\hline \multicolumn{5}{|l|}{ Residence/Division } \\
\hline Kakoba & 292 & \multirow[t]{2}{*}{1.5517} & \multirow[t]{2}{*}{0.213} & \\
\hline Kakika & 81 & & & \\
\hline \multicolumn{5}{|l|}{ Tribe } \\
\hline Banyankole & 262 & \multirow{4}{*}{3.0011} & \multirow{4}{*}{0.391} & \\
\hline Bakiga & 65 & & & \\
\hline Baganda & 30 & & & \\
\hline Rwandese & 11 & & & \\
\hline \multicolumn{5}{|l|}{ Education level } \\
\hline None & 12 & \multirow{4}{*}{4.2446} & \multirow{4}{*}{0.236} & \\
\hline Primary & 195 & & & \\
\hline Secondary & 136 & & & \\
\hline Tertiary & 31 & & & \\
\hline
\end{tabular}




\section{Continued}

\begin{tabular}{|c|c|c|c|c|}
\hline $\begin{array}{l}\text { Have you ever heard of } \\
\text { VCT/HCT screening for HIV? }\end{array}$ & & \multirow{3}{*}{5.4096} & \multirow{3}{*}{0.020} & \\
\hline Yes & 354 & & & \\
\hline No & 20 & & & \\
\hline \multicolumn{5}{|l|}{ What was the source of information? } \\
\hline Friends & 82 & \multirow{4}{*}{2.3494} & \multirow{4}{*}{0.503} & \\
\hline radio/TV & 65 & & & \\
\hline Health worker & 197 & & & \\
\hline Others & 2 & & & \\
\hline \multicolumn{5}{|l|}{$\begin{array}{l}\text { What do you think about } \\
\text { VCT screening for HIV? }\end{array}$} \\
\hline Gives correct results & 141 & \multirow{5}{*}{10.9083} & \multirow{5}{*}{0.028} & \\
\hline Painless & 3 & & & \\
\hline Fear & 26 & & & \\
\hline $\begin{array}{l}\text { Because its voluntary, people are always ready } \\
\text { for the results no matter the outcome }\end{array}$ & 171 & & & \\
\hline I don't know & 23 & & & \\
\hline \multicolumn{5}{|l|}{ Can HIV be cured? } \\
\hline Yes & 66 & \multirow[t]{2}{*}{0.0825} & \multirow[t]{2}{*}{0.774} & \\
\hline No & 302 & & & \\
\hline \multicolumn{5}{|l|}{$\begin{array}{c}\text { Mention the risks that can make an adult } \\
\text { acquire HIV/AIDS }\end{array}$} \\
\hline Not using condoms regularly & 153 & 15.0376 & 0.001 & 0.004 \\
\hline Having more than 1 sexual partner & 13 & & & \\
\hline
\end{tabular}

test $\left(\chi^{2}=5.4096, \mathrm{p}=0.020\right)$. Respondents who had had about VCT testing were less likely to have an HIV positive test compared to those that had no idea on VCT.

A relationship was also established between what the Boda-Boda think about VCT screening for HIV and the current HIV status $\left(\chi^{2}=10.9083, \mathrm{p}=0.028\right)$. Furthermore, it was established that Boda-Boda riders' knowledge about the risks that can make an adult acquire HIV/AIDS was highly associated with the current riders HIV sero-status $\left(\chi^{2}=15.0376, \mathrm{p}=0.001\right)$. Riders who were knowledgeable of the risk of acquiring HIV were less likely to have acquired HIV infection compared to the less knowledgeable.

\section{7) The Logistic regression model}

Significant associations at bivariate analysis were followed up at multivariate analysis using the logistic regression model. The choice of the model was based on the level of measurement of the dependent variable which was nominal with two levels (Yes/No). A reference category was selected for each categorical variable.

Results in Table 7 below revealed that the riders who had never heard of 
Table 7. Results of logistic regression analysis.

\begin{tabular}{lcccc}
\hline Parameter & AOR & p-value & $95 \%$ & CI \\
\hline $\begin{array}{c}\text { Have you ever heard of VCT/HCT screening for HIV? } \\
\text { Yes }\end{array}$ & 1 & & & \\
No & 3.35 & 0.027 & 1.14 & 9.83 \\
$\quad \begin{array}{c}\text { Painless } \\
\text { Fear }\end{array}$ & 1 & & & \\
What do you think about VCT screening for HIV? & 1.11 & 0.867 & 0.3 & 4.1 \\
$\begin{array}{c}\text { Because its voluntary, people are always } \\
\text { ready for the results no matter the outcome }\end{array}$ & 2.05 & 0.084 & 0.91 & 4.64 \\
I don't know & 6.22 & 0.052 & 0.98 & 39.28 \\
$\begin{array}{c}\text { Mention the risks that can make an adult acquire HIV } \\
\text { Buying sex from prostitutes }\end{array}$ & & & & \\
Having more than 1 sexual partner & 6.13 & 0.010 & 1.54 & 4.38 \\
\hline
\end{tabular}

VCT/HCT screening for HIV were more than three times likely to acquire HIV compared to the riders who have ever heard the VCT/HCT screening Adjusted Odds Ratio (AOR) (AOR = 3.35; 95\% CI 1.14 9.83; $\mathrm{p}=0.027$ ).

Furthermore the Boda-Boda riders who didn't know about VCT screening for HIV were more than 6 times to acquire HIV/AIDS (AOR $=6.22$; 95\% CI 0.98 $39.3 ; \mathrm{p}=0.052)$.

\section{Discussion}

This study aimed at establishing the prevalence of HIV among the Boda-Boda riders, social demographic factors predisposing them to HIV and their knowledge on HIV infection. Findings indicate that $91.8 \%$ of the Boda-Boda riders were married to one wife; this was a very good practice in HIV prevention. Studies elsewhere have demonstrated that multiple concurrent sex partners clearly have the potential to accelerate the spread of HIV beyond serial monogamous relationship [17]. In this study, findings further revealed that, Boda-Boda riders who had multiple partners $61.54 \%$ were six times more likely to acquire HIV/AIDS compared to those who buy sex from prostitutes Table 2. From Table 1 the mean age of Boda-Boda was 26.1 years, this reflects a young age of respondents where most jobless youths fall with increased risk of HIV infection. This finding is consonant with findings from a Sero-prevalence of HIV-1 among motorcycle taxi drivers known as okada in Abuja [17] where prevalence of HIV-1 was significant $(\mathrm{p}<0.01)$ among those in age range $26-30$ years with the high prevalence of HIV-1 of $0.63 \%$.

Contrary to the Abuja findings however, HIV prevalence among the Boda Boda riders in current study in Mbarara Uganda was high at 9.9\%, this shows that the Boda-Boda riders are at high risk and they might have contributed to ranking of Mbarara district among the 13 high HIV risk districts in Uganda [18]. 
A study done in Kampala Uganda by Christina et al. [19] found that the prevalence of HIV among the Boda-Boda riders was $7.5 \%$, higher than $4.5 \%$ in other men and national prevalence of age bracket in Uganda. This agrees with World Bank report [20] claim that transport is a high-risk occupation. Other studies already alluded to the fact that the transport sector is a major vector in the transmission of HIV/AIDS [21]. This is because the high mobility of workers enables HIV transmission between high and low prevalence areas. Relatedly, transport sector has been pin pointed in east Africa for the spread of the Novel Corona Virus disease that has devastated the globe in the $21^{\text {st }}$ century. On April $24^{\text {th }}$, Uganda's health minister, Dr. Jane Ruth Aceng reported 12 truck drivers on route from Tanzania and Kenya had tested positive for the novel coronavirus (COVID-19), bringing the total number of cases in the landlocked country up to 75 by then. At the time of writing this study report however, no Boda Boda rider has been implicated or tested positive for COVID-19 in Uganda.

In this study general knowledge of the riders on HIV infection and importance of VCT services was at $80 \%$. This was a good finding and could be attributed to the fact that, Most of the riders had taken more than three years in the Boda-Boda industry together with the fact that the riders had high literacy levels. Table 1, shows that, $53 \%$ had attained primary level of education, $37 \%$ secondary and $8 \%$ tertiary. This could have exposed them to frequent health education sessions from health care providers in the area. This concurs with study findings in Benin in 2005 [22] where riders in transport sector with 1 to 4 years' experience of riding commercial motorcycles had exposed them to health information on HIV prevention. To the researchers dismay however, rider's practices on condom use as a preventive measure were found low at $44.3 \%$ among the respondents. The Boda-Boda rider's good knowledge on HIV prevention by correct use of condoms did not therefore match with the practice. Low condom use in this study could be linked to the problem of multiple sexual partners where other studies have shown inconsistence use of condoms on stable multiple sexual partners.

In this study, $95 \%$ of the respondents were aware of HIV/VCT screening services at least from health workers (Table 6 and Table 7). The finding shows that the Boda-Boda riders are informed about how one can determine their HIV Sero status and even take precautions against HIV. Riders who had never heard of VCT/HCT screening for HIV were three times likely to acquire HIV compared to those who ever heard of VCT/HCT screening (OR $=3.35 ; 95 \%$ CI 1.149 .83 ; $\mathrm{p}$ $=0.027)$. This could be attributed to lack of knowledge on transmission and prevention of HIV and might be attached to failure to articulate health education message more especially among those with no formal education.

\section{Conclusion}

The prevalence of HIV among the Boda-Boda riders in Mbarara municipality at 9.9\% is higher than 5.7\% national HIV prevalence [23] and 6.1\% [18] Mbarara 
district HIV prevalence. The predisposing factors to HIV infection were among others having multiple sexual partners, not having heard of HIV counseling and testing, low and inconsistent condom use at $44.3 \%$. The study recommends health service providers and HIV counselors to intensify awareness and behavior change campaigns on condom use among Boda-Boda riders as preventive measure against HIV.

\section{Limitations}

Due to stigma associated with HIV, some respondents were reluctant to discuss HIV/AIDS. Very sensitive questions like a person living with AIDS or the death of a person of HIV/AIDS were asked last. Some riders were not fluent in spoken English; the study was therefore carried out in both English and Runyankore to special cases by research assistants. Some respondents declined to receive their results but they were tracked through their leaders at all level and further counseling was performed before the release of results. Finally, our data did not include sexual partner type, in particular homosexual partnerships which have been associated with HIV risk among young people. These are areas for further research.

\section{Acknowledgements}

We sincerely acknowledge the Vice Chancellor of Bishop Stuart University Mbarara for the financial support towards completion and publication of the study findings. The team also acknowledges $\mathrm{Mr}$ James Arinaitwe, the chairperson of Boda-Boda Mbarara Municipality and his team for mobilization of Boda-Boda riders in Mbarara Municipality. Our sincere thanks also go to the Town clerk Mbarara Municipality and his team members for granting permission for study.

\section{Conflicts of Interest}

The authors declare no conflict of interest.

\section{References}

[1] Poon, L. (2016) The Love-Hate Relationship between East Africa and Its Two-Wheeled Taxis. City Lab. The Atlantic.

[2] En.wikipedia.org. https://en.wikipedia.org/wiki/Boda_boda

[3] Odwokacen, P. (2015) Urban Transport Regulations and Social Security (Protection) of Commercial Motorcycle Operators (as Informal Sector Employees) in Kampala City; a Leadership Perspective.

[4] Daily Monitor Newspaper Uganda. Friday August 9th 2013.

[5] (2018) Uganda Road Safety Performance Review Report. United Nations, New York and Geneva.

[6] Larcedida, R., Gravato, N., McFarland, E.W., Rutherford, G., Iskrant, K.S. and Hearsat, N. (1997) Truck Drivers in Brazil: Prevalence of HIV and Other Sexually Transmitted Diseases, Risk Behavior and Potential for Spread of Infection. Aids, 11, 
S15-S19.

[7] Mafigiri, R., Matovu, J.K.B., Makumbi, E., Ndyanabo, A., Nabukalu, D., Sakor, M., Kigozi, F.G., Nalugoda, F. and Wanyenze, K.R. (2017) HIV Prevalence and Uptake of HIV/AIDS Services among Youths (15-24 Years) in Fishing and Neighboring Communities of Kasensero, Rakai District, South Western. BMC Public Health, 17, Article No. 251. https://doi.org/10.1186/s12889-017-4166-2

[8] UNAIDS (2019) Fact Sheet-World Aids Day 2019.

[9] UNESCO (2014) AVRT.org. https://.avert.org/professionals/hiv-social/key-affected-populations/young-people

[10] Howe, J. and Annabel, D. (2002) Boda-Boda-Uganda's Rural and Urban. https://www.researchgate.net/publication/264399616_Boda_boda_Ug

[11] UNAIDS \& UNESCO (2013) Young People Today-Time to Act Now.

[12] Rosenberg, N., et al. (2913) Assessing the HIV Counseling and Testing on HIV Acquisition among South African Youth. AIDS Journal, 27, 2765-2773. https://doi.org/10.1097/01.aids.0000432454.68357.6a

[13] USAID Fact Sheet (2015) Condoms for Prevention of HIV Transmission.

[14] UNAIDS (2016) Prevention Gap Report.

[15] UNICEF (2013) Towards an AIDS-Free Generation: Children and AIDs Sixth Stocktaking Report.

[16] Morris, M. and Kretzschmar, M. (1997) Concurrent Partnerships and the Spread of HIV. Aids, 11, 641-648. https://doi.org/10.1097/00002030-199705000-00012

[17] Mohammed, S.B., Ya’aba, Y., Abarike, M.C. and Baba, J. (2019) Sero-Prevalence of Human Immunodeficiency Virus (HIV-1) among High Risk Groups in Abuja, Nigeria. Open Journal of Epidemiology, 9, 89-103. https://doi.org/10.4236/ojepi.2019.91009

[18] Taremwa, A. (2013) Mbarara among the 13 High HIV Risk Districts in Uganda.

[19] Lindan, C.P., Anglemyer, A., Hladik, W., Barker, J., Lubwama, G., Rutherford, G., Ssenkusu, J., Opio, A. and Campbell, J. (2015) High-Risk Motorcycle Taxi Drivers in the HIV/AIDS Era: A Respondent-Driven Sampling Survey in Kampala, Uganda. International Journal of STD \& AIDS, 26, 336-345. https://doi.org/10.1177/0956462414538006

[20] World Bank Report (2003) Transport Is Considered a "High-Risk" Occupation.

[21] HIV/AIDS KMCC (2014) Most at Risk Populations-Long Distance Truck Drivers and HIV/AIDS in Uganda: Synthesis of Information and Evidence to Inform the Response.

[22] Adeoye, S. (2005) Sexual Behavior, Perception of HIV/AIDS and Condom Use among Commercial Motorcyclists in Benin City. Nigerian Postgraduate Medical Journal, 12, 262-265.

[23] Uganda HIV and AIDS (2018).

https://www.avert.org/professionals/hiv-around-world/sub-saharan-africa/uganda 